\title{
Taxonomic and biogeographic notes on the genus Pyrus L. (Rosaceae): a new record and a new synonym, with data on seed morphology
}

\author{
Zübeyde Uğurlu Aydın ${ }^{1}$ \\ Ali A. Dönmez \\ Department of Biology, Faculty of Science, Hacettepe University, \\ Beytepe, Ankara, Turkey.
}

\begin{abstract}
Species of the genus Pyrus distributed in Europe include $P$. communis L., P. pyraster, $P$. nivalis Jacq., and $P$. cordata Desv. subsp. cordata. Pyrus pyraster is occasionally regarded as a variety or subspecies of $P$. communis. However, a molecular study has recently demonstrated that $P$. communis is more closely related to $P$. caucasica and $P$. nivalis, rather than to $P$. pyraster. In this study, Pyrus pyraster is reported from Turkey for the first time. Pyrus vallis-demonis, a species recently described from Italy, is here reduced to a synonym of Pyrus pashia based on morphology. Also, we discuss seed ornamentation of Pyrus pashia and a closely related taxon, $P$. cordata subsp. boissieriana, to achieve a better understanding of taxonomy in the group.
\end{abstract}

Key Words: biogeography, Italy, new record, synonym, seed morphology, Turkey

\section{INTRODUCTION}

Rosaceae is widespread throughout the world but the family diversified mainly in the Northern Hemisphere. It includes approximately 3000 species in 100 currently recognized genera [Kalkman, 2004]. Pyrus L. is the genus of trees with a number of species being estimated from 41 to 73 [Robertson et al., 1991; Browicz, 1993] and according to recent nomenclatural changes, it was placed under subfamily Maloideae, tribe Maleae Small, subtribe Malinae [Reveal, 2012a, b]. However, a new dramatic re-circumscription of Pyrus was recently proposed by Christenhusz [Christenhusz et al., 2018], who proposed to merge under Pyrus a wide array of previously widely recognized genera. Here we accept Pyrus in its traditional moderately narrow sense.

Pyrus taxa are divided into Occidental and Oriental pears in accordance with geographical distribution [Bailey, 1917] and this was also confirmed by later phylogenetic studies [Korotkova et al., 2018]. Occidental taxa are distributed in Europe, North Africa, Turkey,

Accepted for publication: 15 May 2019

1'E-mail: zubeydeugurlu@gmail.com
Iran, Central Asia and Afghanistan, while oriental pears are widespread in East Asia. Pyrus pashia is accepted as a link between Occidental and Oriental pear species [Rubtsov, 1944; Zheng et al., 2014] because it is native to China, Bhutan, India, Kashmir, Laos, Myanmar, Nepal, the western part of Pakistan, Thailand, Vietnam, Afghanistan [Gu \& Spongberg, 2003], and have been also recently recorded from northeastern Iran [Zamani et al., 2009]. It is placed in Pyrus sect. Pashia, with morphologically similar $P$. cordata Desv. subsp. boissieriana (Buhse) Uğurlu \& Dönmez. These taxa also share similar distribution patterns, and their taxonomic delimitations remain unclear [Zamani et al., 2009]. In order to close this gap, a detailed description of P. pashia and seed characters of the two taxa have been evaluated here.

Four Pyrus species are reported for Italy [Pignatti, 1982] and the following four new taxa have been recently described [Marino et al., 2012; Raimondo \& Schicchi 2004; Raimondo et al., 2006a, 2006b] from there: P. vallis-demonis Raimondo \& Schicchi, $P$. sicanorum Raimondo, Schicchi \& P. Marino, $P$. castribonensis Raimondo, Schicchi \& Mazzola, and P. ciancioi P. Marino, G. Castellano, Raimondo \& Spadaro. However, our studies in the field, along with herbarium and literature research, demonstrate that the type specimen of $P$. vallis-demonis is conspecific with P. pashia Hamilton ex D. Don. This taxonomically and geographically important finding is discussed below.

Another pear species, P. pyraster (L.) Burgsd., is reported here for the first time for Turkey. Detailed descriptions of the new record and P. pashia, with comments on geographic distribution patterns, are presented in the study. An updated distribution map of P. cordata, P. pashia and P. pyraster are prepared based on herbarium specimens and literatures [Chater et al., 1968; Schönbeck-Temesy, 1969; Kurtto 2009].

\section{MATERIAL AND METHODS}

Specimens of Pyrus pyraster were collected from the northwestern part of Turkey, Kirklareli, and specimens of $P$. pashia were collected in Iran during field trips by the second author. Type material of $P$. vallisdemonis was examined in the PAL (Orto Botanico dell’Università degli Studi di Palermo, Palermo, Italy) 
herbarium. Herbarium sheets of $P$. pyraster were seen in LE (Komarov Botanical Institute of RAS, Saint Petersburg, Russia) and images of the sheets in virtual herbaria of P (Muséum National d'Histoire Naturelle, Paris, France), WU (Universität Wien, Wien Austria), BM (The Natural History Museum, London, U.K.), K (Royal Botanic Gardens, London, U.K.) and E (Royal Botanic Garden Edinburgh, Edinburgh, U.K. Scotland). For SEM studies, seeds of taxa were washed with $70 \%$ alcohol and coated with a gold-palladium mixture. Photomicrographs were taken with a Zeiss EVO 50 EP electron microscope. Specimens of the new record are deposited at HUB (Hacettepe University, Ankara, Turkey).

\section{RESULTS AND DISCUSSION}

Taxonomic treatment. Pyrus pyraster (L.) Burgsd., Anl. Erzieh. Holzart. 2: 193. 1787. Fig. 1.

Tree up to 6-8 $\mathrm{m}$, bark dark grey to grey; branches glabrous, spiny. Leaves $(2.5-) 3-7 \times(2-) 3-5 \mathrm{~cm}$, obovate to ovate; acute or obtuse at apex, with mucro; shortly cuneate at base; margin clearly serrate or dentate at least in the upper half of lamina, tomentose on both sides at flowering stage, later becoming glabrous. Petioles (1.5-) 3-4.5 cm long, glabrous or with few hairs. Stipules $10 \times 1 \mathrm{~mm}$, linear, deciduous. Inflorescence a corymb of 8-12 flowers. Bracts (7-) $10 \mathrm{~mm}$ long, subulate, pubescent, deciduous. Hypanthium concave, cupuliform, densely tomentose outside. Sepals 3-5 $\times$ 2-3 mm, oblong, reflexed, densely tomentose, mostly persistent at fruit. Petals $8-12 \times 7-10 \mathrm{~mm}$, white; margin entire, apex rounded, ovate to widely ovate, with short claw. Stamens in two rows, 20-22, unequal. Styles $3-5$, free, sparsely pubescent at base. Fruits $2-3(-3.5)$ $\times 1.5-2.5(-3.5) \mathrm{cm}$, brownish, globose to subglobose, with numerous stone cells. Pedicels $3-3.5(-5.5) \mathrm{cm}$, thick. Seeds $4-6 \times 3-4 \mathrm{~mm}$, ovate, pale-brown to dark brown.

Distribution: Armenia, Southwestern and Central Europe, Northwest of Turkey.

Ecology: Open hills, roadsides, mostly solitary.

Phenology: Flowering in May, fruiting in August to November.

Specimens Examined. Austria. Niederösterreich [Lower Austria]: Thermenlinie, Traiskirchen, wenig nördlich der Mandlhohkapelle (= Kote 256) N 48 $1^{\prime} 56^{\prime \prime}$, E $16^{\circ} 16$ '13", 243 m, 16.7.2011, Till W. 110863 (WU photo!). Niederösterreich [Lower Austria], NSG Bisamberg, Eichenmischwald-Saum N 48 18'46", E 16 $21^{\prime} 46^{\prime \prime}$, 360 m, 17.8.2011, Schumacher F., FS 110817/1 Tod F.

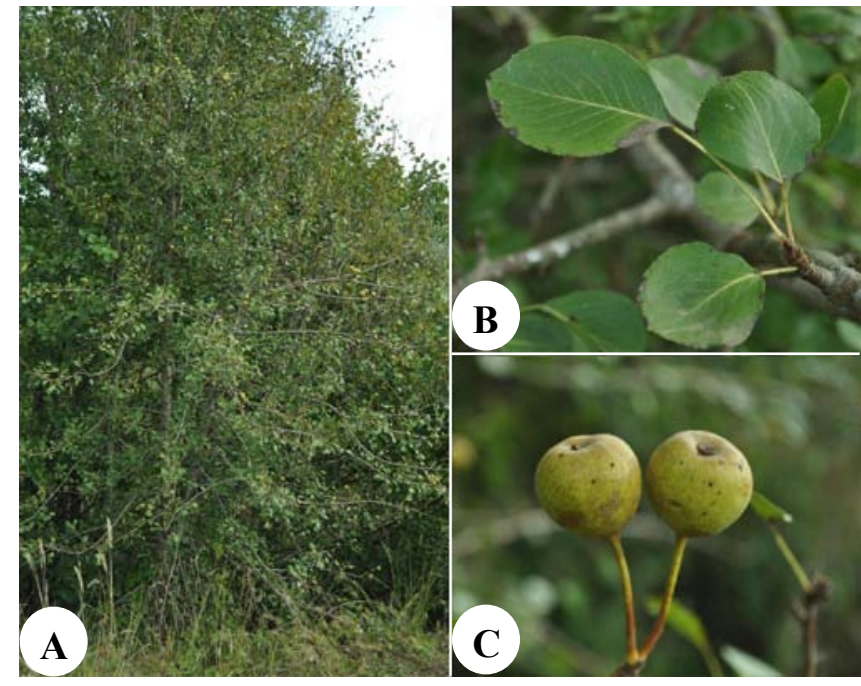

Figure 1. Pyrus pyraster. A: habit; B: leaves; C: fruit (ZUG466, photographed by A.A. Dönmez).

(WU photo!).

Zangezure, 29.9.1936, A.J. Pojarkova (LE!).

Turkey. Kırklareli: 5. km from Dereköy to Şükrüpaşa,

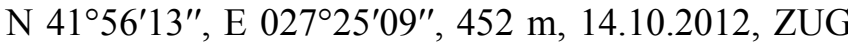
466-A. A. Dönmez (HUB!).

Pyrus pashia Buch.-Ham. ex D.Don. in Prodr. Pl. Nep. 236 (1825). Fig. 2.

Type: (Schönbeck-Temesy, 1969) Nepal, Naraihetty, Hamilton s.n. (BM000522006 photo!).

$=P$. variolosa Wall. in Numer. List [Wallich] n. 680 .

1829, nom. illeg.

$=P$. verruculosa Bertol. in Mem. Reale Accad. Sci. Ist.

Bologna, Ser. 2, 4: 312 (1864).

$=P$. nepalensis Herb. Herb. Hamilt. et Hort, ex Hooker in FL Brit. Ind. II, 374 (1879).

$=P$. vallis-demonis Raimondo \& Schicchi in Bocconea

17: 327: 325-330, figs. 1-3, (2004). syn. nov.

(Holotype PAL!). Fig. 2B-D.

Tree up to $12 \mathrm{~m}$, bark dark grey to grey; branches glabrous, spiny. Leaves $\left(2.5^{-}\right) 4-8(-12) \times 1.5-3(-5)$ $\mathrm{cm}$, ovate or broadly ovate or lanceolate-ovate; acuminate to apiculate at apex, rounded to subcordate at base; margin serrate to serrulate; tomentose on both sides at flowering stage, later becoming glabrous on upper surface, sparsely tomentose or glabrous on lower surface. Petioles $1.5-3(-5) \mathrm{cm}$ long, initially pilose, soon becoming glabrescent. Stipules $10 \times 2 \mathrm{~mm}$, linear-lanceolate, deciduous. Inflorescence a corymb of 7-13 (-18) flowers. Bracts 8-10 mm long, subulate, pubescent, brownish, deciduous. Hypanthium cupular, abaxially tomentose. Sepals 3-6 × 2-3 mm, triangular-oblong, 
acute, densely tomentose outside, or both surfaces tomentose, mostly deciduous at fruit. Petals $8-10 \times 4-6$ $\mathrm{mm}$, white, apex rounded, short claw at base. Stamens in two rows, 15-20 (25), unequal. Styles 3-5, free, base \pm pubescent. Fruits $\left(0.8^{-}\right) 2 \times\left(0.5^{-}\right) 1.5 \mathrm{~cm}$, yellowishbrown, shiny, subglobose to pyriform, covered with pale or white lenticels. Pedicel (1.8-) 2-3 (-4.5) cm, subglabrous. Seeds $3-5 \times 1.5-2 \mathrm{~cm}$, ovate, blackish, surface covered by unequal diametric cells, sculpturing smooth, cell wall markedly thick.

Distribution: China, Bhutan, India, Kashmir, Laos, Myanmar, Nepal, W. Pakistan, Sikkim, Thailand, Vietnam, Afghanistan, Iran, and Italy (Fig. 3).

Ecology: Grows in valleys, with Paliurus spina-christi Mill., Quercus sp. at 600-3000 m.

Phenology: Flowering in mid- to late April, fruiting in late August to late September.

Specimens examined. Afghanistan. Remaudiere s.n. (P04341326 photo!).

China. Yunnan: les bois à Kiao che Tong, montée de Hee-chan-men (Hokin), 12.10. 1885, Delavay J.M. 1994 (P01819383 photo!). Prov. de Kiang-Si, 1893, David A. 919 (P01819384 photo!).

India. Himalaya: Kumaon, R. Strachey 6, 5000 -8000, (P01819389 photo!).

Italy: Sicilia, Nebrodi, Tassita di Caronia 1440 m s.l.m., N 3753'49.8', E14²9'03,07", 30. 08. 1999, Raimondo \& Schicchi (PAL!).

Iran. Khorasan: north of Khorasan, Bojnurd, Tain vil-

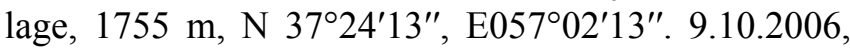
A.A. Dönmez 14102 (HUB!).

Laos. border of Pakse, Boloven Plateau, E. Poilane 28397 (P00330610 photo!).

Mynanmar. Mynanmar (Burma), (E00908645 photo!).

Nepal. Nepala (et) Ramoun, 1829, Wallich 680 (K000758085 photo!, E 00010846 photo!).

Vietnam. Tonkin: Province Lang Son, Tam-Lung village, E. Poilane 29735 (P00330604 photo!).

European Pyrus taxa include $P$. communis L., $P$. pyraster, $P$. nivalis Jacq., and $P$. cordata Desv. subsp. cordata. Among them, P. pyraster is occasionally regarded by some authors [Rehder 1949; Kurtto 2009] at a variety or subspecies rank under $P$. communis. However, recently a molecular study demonstrated that $P$. communis is more closely related to $P$. caucasica and $P$. nivalis, rather than to $P$. pyraster [Zheng et al., 2014]. It is also distinctly different from $P$. communis in having dentate margins of leaves (Fig. 1B). According to molecular phylogeny and morphology, the new record is accepted as a species level for the Turkish flora. With this new record, all European species are now reported as occurring in Turkey [Browicz, 1972; Kurtto, 2009; Uğurlu Aydın \& Dönmez, 2015].

F.M. Raimondo and R. Schicchi (2004) described Pyrus vallis-demonis mainly based on small fruit with deciduous calyx (Fig. 2D) and emphasized its morphological similarities to P. cordata. Among the genera, large fruits that have five carpels known as European Pyrus taxa while Asian pears have small fruits that have two carpels [Silva et al., 2014]. In Asian pears, two of them, $P$. pashia and P. calleryana have deciduous calyx and obtusely serrate margin and one of the differences between them is styles numbers. $P$. calleryana has 2 or 3 styles while $P$. pashia is characterised with 3-5 styles [Gu, Spongberg, 2003]. The second styles number were also observed for $P$. vallis-demonis based on protologue. Moreover, deciduous calyx and small fruits bearing whitish dot on the surface were accepted as diagnostic characters for the section Pashia [Browicz, 1993]. It is obvious that $P$. vallis-demonis is a member of Asian pears and but also sec. Pashia. Based on the comparison of specimens belonging to $P$. vallis-demonis and P. pashia (Fig. 2) and relevant literature [SchönbeckTemesy 1969; Gu, Spongberg, 2003] we concluded that it is not a new species, but a new synonym of $P$. pashia.

Pyrus pashia occur in eastern Afghanistan, northern Pakistan, India up to China, northern Vietnam, and Thailand [Browicz, 1993; Gu, Spongberg, 2003]. Recently it was reported as a new record for the flora of Iran (Fig. 3) [Zamani et al., 2009]. It is therefore accepted as an intermediate link between occidental and oriental groups [Rubtsov, 1944; Federov, 1958; Gladkova, 1990]. With its newly added synonym, P. pashia is now reported in Europe for the first time. This finding changes the geographic range of the taxon, with its distribution being expanded westward. It is known that range expansion plays an important role in the current phylogeographic structure of taxon [Liu et al., 2013].

It is suggested that Pyrus taxa originated in the mountainous regions of western China and its dispersion followed the mountain ranges to both the east and the west [Rubtsov, 1944; Zielinski, Thompson, 1967]. Therefore, western Eurasia including Turkey to eastern Asia became important for species diversification [Silva et al., 2014]. P. pashia has not been reported for Turkey (Fig. 3) and suprisingly it is counted for Italian flora. However, it could be found in the montain range of Turkey like $P$. cordata.

Pyrus pashia and its closely related taxon, $P$. cordata 


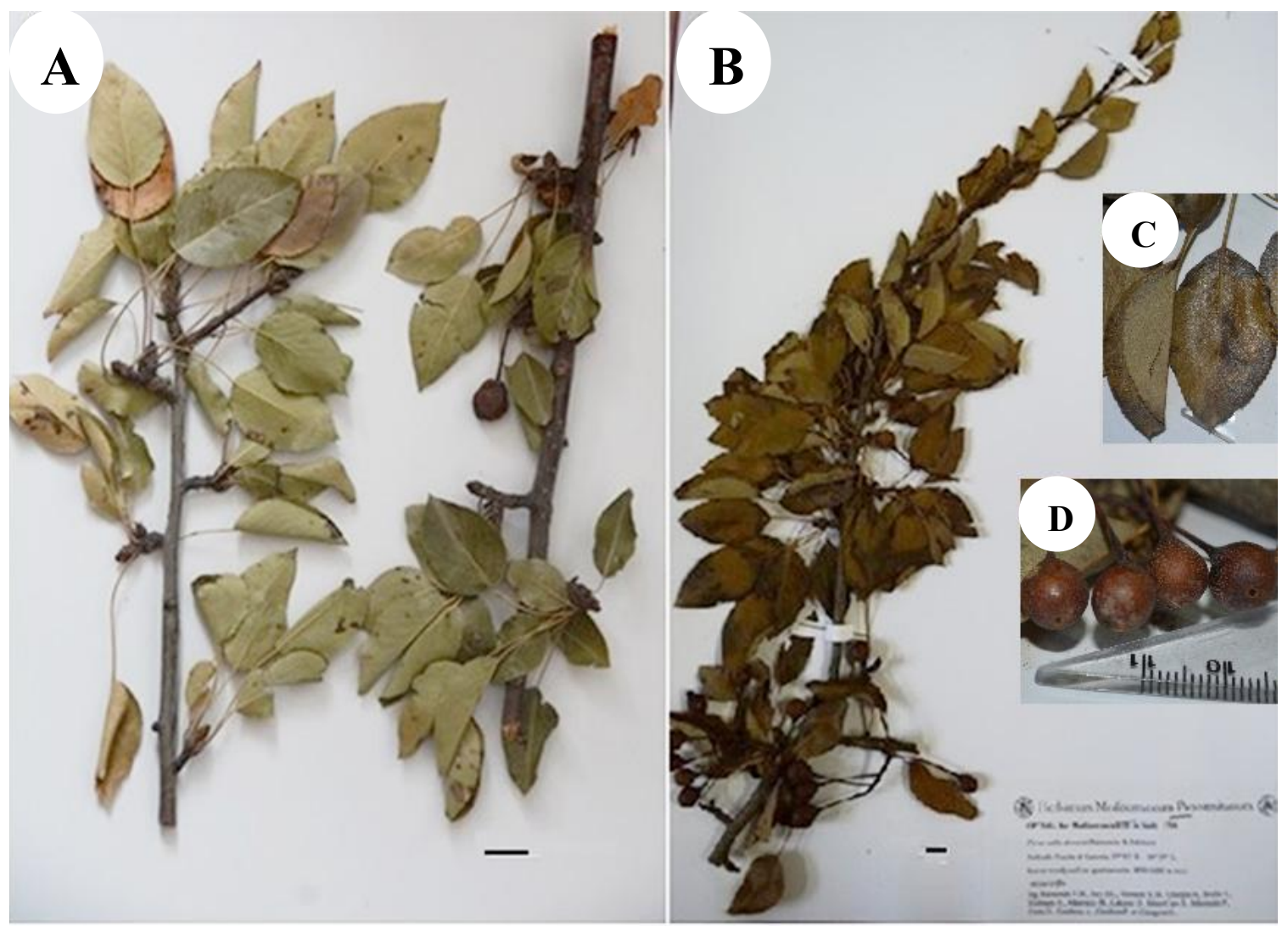

Figure 2. Pyrus pashia and P. vallis-demonis. A: P. pashia-A.A. Dönmez 14102; B: holotype of $P$. vallis-demonis; C: leaves; D: fruits. Scale bars $=2 \mathrm{~cm}$.

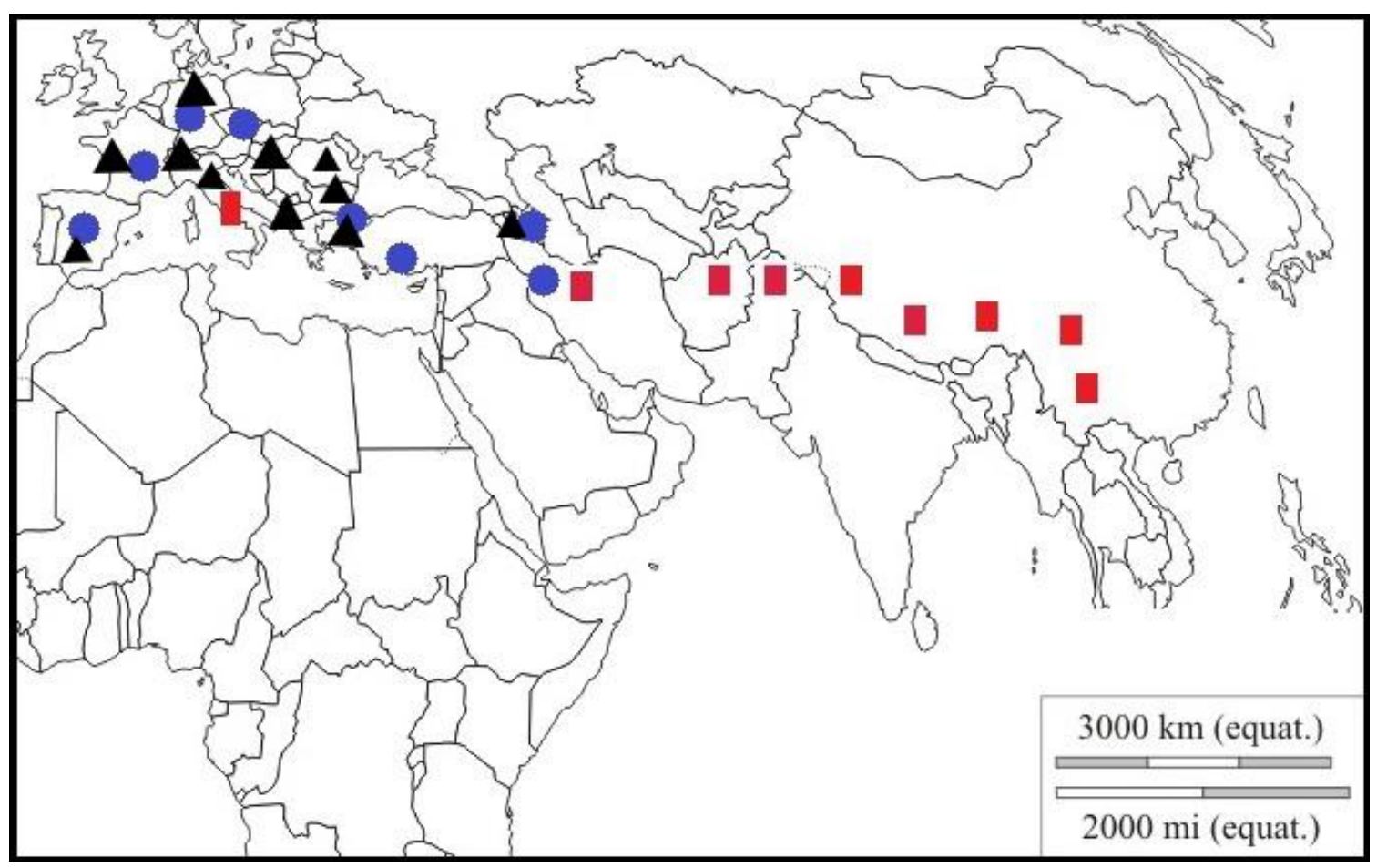

Figure 3. Distribution map of Pyrus pashia (red square), P. cordata (blue circule) and P. pyraster (black triangle) based on herbarium specimens and literature. 


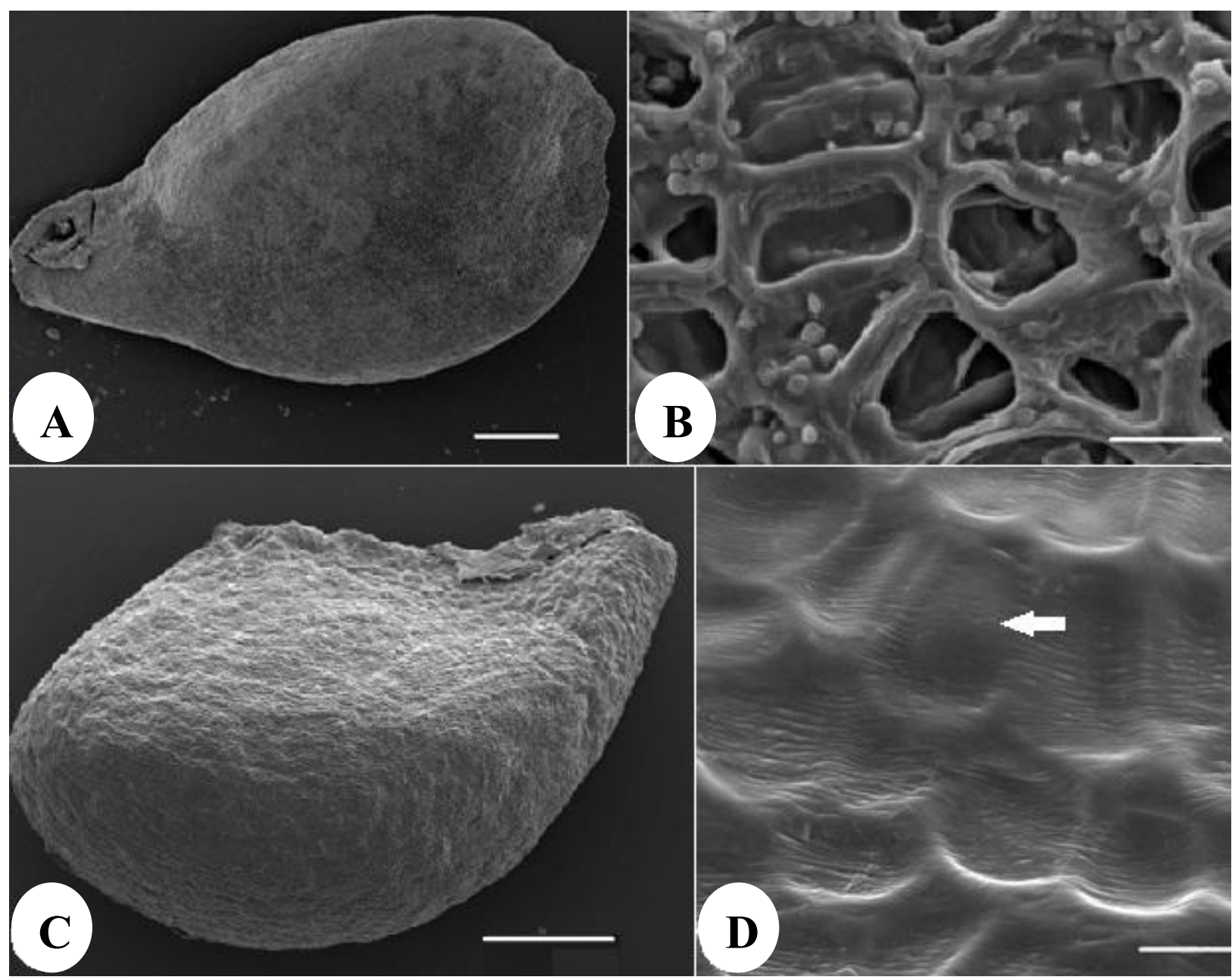

Figure 4. Seed morphology of Pyrus pashia and P. cordata. A: P. pashia; B: testa sculpture of P. pashia - AAD 14102; C: P. cordata; D: testa sculpture of P. cordata-ZUG 483 (white arrow shows rounded projection). Scale bars: $\mathrm{A}, \mathrm{C}=10 \mu \mathrm{m} ; \mathrm{B}, \mathrm{D}=100 \mu \mathrm{m}$.

subsp. boissieriana, are members of section Pashia Koehne, and $P$. pashia differs from the latter in having only ovate-lanceolate leaves with \pm long acuminate apex [Schönbeck-Temesy, 1969]. Zamani et al. [2009] underlined that additional diagnostic characters are essential for understanding taxonomic relationships of these close taxa. Therefore, seed characters were studied using SEM in the two species (Fig. 4).

Comparative seed morphology shows that surface sculpturing has diagnostic features to differentiate the two taxa. Pyrus pashia has smooth ornamentation with covered thick cell wall whereas $P$. cordata subsp. boissieriana presents short striate ornamentations with inconspicuous cell wall. Also, testa epidermis of two taxa are generally rectangular or polygonal but some testa cells of $P$. cordata subsp. boissieriana consist of rounded projections on the middle (Fig. 4D).

Additional specimen examined. Pyrus cordata subsp. boissieriana.

Azerbaijan: Baku, distr. Lankeran, 19.06.1916, A. Grossheim, Institute of Botany, Ilia State University, Tbilisi, Georgia (TBI!).

Iran: Mazenderan, Road from Mazenderan to Karaj, 2100 m, 21. 09. 2005, A.A.Dönmez 12541- M. Atoi \& E. Esreti (HUB!); Tehran, Road from Firuz Kut to Emirir,

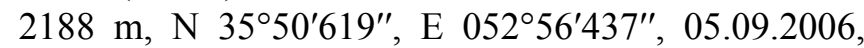
A.A. Dönmez 14059 - G. Zare \& M. Suzani (HUB!); Coastal Plain, 16. 8. 1960 Zohary \& Zohary No 862 (HUJ!).

Turkey: Antalya, Gündoğdu, 15 m, N 3651'676", E 03116'692", ZUG 200- A.A. Dönmez; ZUG 201- A.A. Dönmez; Gündoğdu, Bereket village around, $18 \mathrm{~m}, \mathrm{~N}$ 36 53'586", E 031'13'145", 09.11.2012, ZUG 483A.A. Dönmez (HUB!); Road junction of Gündoğdu, $21 \mathrm{~m}, \mathrm{~N} 36^{\circ} 52^{\prime} 364^{\prime \prime}$, E $031^{\circ} 15^{\prime} 761^{\prime \prime}$, ZUG 486(HUB!); ibid. ZUG 487-A.A. Dönmez (HUB!); A road from 
Manavgat river bridge to Serik, $3 \mathrm{~m}, \mathrm{~N} 36^{\circ} 46^{\prime} 526^{\prime \prime}$, E 031 ${ }^{\circ} 20^{\prime} 602^{\prime \prime}, 16.03 .2013$, ZUG 488- A.A. Dönmez (HUB!); Highway to Beşkonak, $51 \mathrm{~m}, \mathrm{~N} 36^{\circ} 55^{\prime} 333^{\prime \prime}$, E 031 13'872", 26.09.2012, A.A. Dönmez 18206 -Z. Uğurlu (HUB!); 17 km South of Serik, 16.08.1959, M. \& D. Zohary 3092 (HUJ!).

\section{ACKNOWLEDGEMENT}

The authors are grateful to TUBITTAK (Project No: 111 T 850) for financial support. Kind assistance of the herbarium curators of PAL, TBI, HUJ and LE is greatly appreciated.

\section{REFERENCES}

Browicz K. (1972). Pyrus L. In: Flora of Turkey and the East Aegean Islands, vol. 4, Davis P.H. (Ed.). Edinburgh, UK: Edinburgh University Press, 160-168.

Browicz K. (1993) Concept and chorology of the genus Pyrus L. Arboretum Kórnickie 38: 17-33.

Bailey L.H. (1917) Pyrus L. In: Standard cyclopedia of horticulture, vol. 5. New York, USA: Macmillan, 2865-2878.

Chater A.O., Webb D.A. (1968) Pyrus L. In: Flora Europaea, vol. 2, Tutin T.G., Heywood V.G., Burges N.A., Moore D.M., Valentine D.H., Walters S.M., Webb D.A.(Eds). Cambridge, UK: Cambridge University Press.

Christenhusz M.J.M., Fay M.F., Byng J.W. (Eds.) (2018) The Global Flora. vol. 4: Special Edition, GLOVAP Nomenclature Part 1. Plant Gateway Ltd., Bradford, United Kingdom, $155 \mathrm{pp}$.

Fedorov A. A. (1958). On floristic links between East Asia and the Caucasus (on the example of the genus Pyrus). In: Material on the history of flora and vegetation of the USSR 3, Moscow-Leningrad.

Gladkova V.N. (1990). Review of species of the genus Pyrus L. (Rosaceae) from Caucasian flora. Botanical journal, 75: 874-883.

Gu C., Spongberg S.A. (2003) Pyrus L. In: Wu Z.-Y., Raven P.H., Hong D.-Y. (Eds.), Flora of China: vol. 9, Science Press (Beijing) \& Missouri Botanical Garden Press (St. Louis), 173-179.

Kalkman C. (2004) Rosaceae. In: Kubitzki K. (Ed.), The families and genera of vascular plants: vol. 6, Berlin: Springer, 343-386.

Korotkova N., Parolly G., Khachatryan A., Ghulikyan L., Sargsyan H., Akopian J., Borsch T., Gruenstaeudl M. (2018) Towards resolving the evolutionary history of Caucasian pears (Pyrus, Rosaceae) - Phylogenetic relationships, divergence times and leaf trait evolution. J Syst Evol, 56: 35-47.

Kurtto A. (2009). (continuously updated) Euro+Med Plantbase - the information resource for Euro-Mediterranean plant diversity [online]. http://www.emplantbase.org/ [accessed September 2018].

Liu J., Sun P., Zheng X., Potter D., Hu C. (2013) Genetic structure and phylogeography of Pyrus pashia L. (Rosaceae) in Yunnan Province, China, revealed by chloroplast DNA analyses. Tree Genet Genomes, 9(2): 433-441. doi: 10.1007/s11295-012-0564-x.

Marino, P., Castellano, G., Raimondo, F.M. \& Spadaro, V. 2012: Pyrus ciancioi (Rosaceae), a new species from Sicily. Plant Biosyst146(3): 654-657.

Pignatti S. (1982) Pyrus L. In: Pignatti S., Riccardo G., Marco L.R. (Eds.), Flora d'Italia vol. 3. Bologna: Edagricole-New Business Media press.

Raimondo F.M., Schicchi R. (2004) Pyrus vallis-demonis (Rosaceae), a new species from the Nebrodi Mountains (NE-Sicily). Bocconea 17: 327.

Raimondo F.M., Schicchi R., Marino P. (2006a) Pyrus sicanorum (Rosaceae) a new species from Sicily. Flora Mediterranea, 16: 379-384.

Raimondo F.M., Schicchi R., Mazzola P. (2006b) Pyrus castribonensis (Rosaceae) nuova specie della Sicilia. Nat. sicil., ser. 4, 30(3-4): 363-370.

Rehder A. (1949) Bibliography of cultivated trees and shrubs. Massachusetts: The Arnold Arboretum of Harvard University, p. 825.

Reveal J.L. (2012a) Newly required infrafamilial names mandated by changes in the Code of nomenclature for algae, fungi and plants. Phytoneuron, 33: 1-31.

Reveal J.L. (2012b.) An outline of a classification scheme for extant flowering plants. Phytoneuron, 37: $1-221$.

Robertson K.R, Rohrer J.R., Rohrer J.B., Smith P.G. (1991) A synopsis of genera in subfamily Maloideae (Rosaceae). Syst Bot., 16: 376-394.

Rubtsov G.A. (1944) Geographic distribution of the genus Pyrus and trends and factors in its evolution. $\mathrm{Am}$ Nat., 78(777): 358-366.

Schönbeck-Temesy E. (1969) Pyrus L. In: Flora Iranica, vol. 66, Rechinger K.H. (Ed.). Austria, Graz: Akademische Druck-u. Verlagsanstalt.

Silva G.J., Souza T.M., Lía Barbieri R., Costa de Oliveira A. (2014). Origin, pomestication and dispersing of pear (Pyrus spp.). Advances in Agriculture, https:// doi.org/10.1155/2014/541097.

Uğurlu Aydın Z., Dönmez A.A. (2015). Taxonomic and nomenclatural contributions to Pyrus L. (Rosaceae) 
from Turkey. Turk J Bot. 39: 841-849. doi: 10.3906/ bot-1411-34.

Zamani A., Attar F., Joharchi M.R. (2009) Pyrus pashia (Rosaceae), a new record for the flora of Iran.Iran J Bot., 15(1): 72-75.

Zheng X., Cai D., Potter D., Postman J., Liu J., Teng Y. (2014) Phylogeny and evolutionary histories of $P y$ rus L. revealed by phylogenetic trees and networks based on data from multiple DNA sequences. $\mathrm{Mol}$ Phylogenet Evol., 80: 54-65.

Zielinski Q.B., Thompson M.M. (1967) Speciation in Pyrus: chromosome number and meiotic behavior. Bot Gaz., 128: 109-112.

\section{Pyrus L. (Rosaceae) cinsinə dair taksnomik və biocoğrafi qeydlor: toxum morfologiyası məlumatları ilə yeni ad və yeni sinonim}

\section{Zübeydə Uğurlu Aydın, Ali A. Dönməz}

Biologiya şöbəsi, Elm fakültəsi, Hacettepe Universiteti, Beytepe, Ankara, Türkiyo

Avropada bitən Pyrus cinsinin taksonlarına P. comunis, $P$. pyraster, $P$. nivais və $P$. cordata subsp. cordata aiddir. Onlardan $P$. pyraster bir sira müəlliflər tərəfindən $P$. communis növünün variasiyası və ya yarımnövü kimi göstərilmişdir. Bu tədqiqat işində P. pyraster ilk dəfə olaraq Türkiyədən təqdim edilir. Növ son zamanlarda İtaliyadan təsvir edilmişdir və burada morfologiyaya əsasən $P$. pashia növünün sinoniminə keçirilmişdir. Həmçinin bu qrupun taksonomiyasını daha yaxşı dərk etmək üçün $P$. pashia və ona yaxın $P$. cordata subsp. boissieriana toxumunun quruluşu (naxış1) müzakirə edilir.

Açar sözlor: biocoğrafiya, İtaliya, yeni molumat, sinonim, toxum morfologiyası, Türkiyə.

Таксономические и биогеографические заметки о роде Pyrus L. (Rosaceae): новый вид и новый синоним, согласно данным морфологии семян

\section{Зубейда Угурлу Айдын, Али Донмез}

Биологический отдел, Факультет естественных наук, Университет Xасетmепе, Бейтепе, Анкара, Туричи

К Европейским таксонам рода Pyrus относятся $P$. comunis, $P$. pyraster, $P$. nivais и $P$. cordata subsp. cordata. Среди них $P$. pyraster некоторыми авторами рассматривается как вариация или подвид $P$. communis. Однако недавно проведенные молекулярные исследования показали, что $P$. communis более близок к P. caucasica и P. nivalis, чем к P. pyraster. В этом исследовании P. pyraster впервые представлен из Турции. Вид Pyrus vallisdemonis недавно описан из Италии, здесь на основе морфологических данных этот вид проведен в синонимы P. pashia. Также нами обсуждалась орнаментация семян $P$. pashia и близкий к нему $P$. cordata subsp. boissieriana для уточнения таксономии группы.

Ключевые слова: биогеография, Италия, новый рекорд, синоним, семенная морплогия, Турция. 